\title{
Choosing Life with Spinal Muscular Atrophy Type 1
}

Moran Lavie · Hodaya Nisnkorn · Liora Sagi · Israel Amirav

Received: March 16, 2020 / Published online: April 18, 2020

(C) The Author(s) 2020

\section{ABSTRACT}

This article is co-authored by the mother of a patient with spinal muscular atrophy (SMA), two pediatric pulmonologists and the pediatric neurologist in the team. It describes the patient and their family's experience of living with SMA. This commentary describes the mother's experience of the diagnosis and treatment process of her daughter's SMA in an era of emerging treatments for a disease which was until recently considered incurable. SMA diagnosis and management in the context of the patient mother's experiences is discussed.

Digital Features To view digital features for this article go to https://doi.org/10.6084/m9.figshare.12074715.

M. Lavie $(\bowtie) \cdot$ H. Nisnkorn · I. Amirav

Pediatric Pulmonology Unit, Dana-Dwek Children's Hospital, Tel-Aviv Sourasky Medical Center, Sackler

Faculty of Medicine, Tel Aviv University, Tel Aviv, Israel

e-mail: moranla@tlvmc.gov.il;

laviemoran@gmail.com

L. Sagi

Pediatric Neurology Institute, Dana-Dwek

Children's Hospital, Tel-Aviv Sourasky Medical

Center, Sackler Faculty of Medicine, Tel Aviv

University, Tel Aviv, Israel
Keywords: Antisense oligonucleotide; Intrathecal injections; Motor neuron disease; Nusinersen; Spinal muscular atrophy

\section{Key Summary Points}

Spinal muscular atrophy 1 (SMA1) is a devastating neuromuscular disorder.

The past 2 years have witnessed dramatic changes with the introduction of 2 new treatments for SMA.

We present here an account of a true team effort to provide urgent, lifesaving treatment for a baby girl with SMA1.

This is the story of how a partnership of a family and a medical team was, and still is, the driving force that made all the difference.

\section{PATIENT'S EXPERIENCE: MOTHER'S PERSPECTIVE}

When Daria was born, a third daughter for Gil, my husband, and me, what struck me most about her was her profound desire to communicate with others. She smiled at a very early age. She used to look around and make funny 
noises whenever people were nearby. She was a beautiful, happy baby girl and it was a very happy time for our family. When Daria was around 2 months old, her grandparents started pointing out that she was having trouble moving her arms and turning and raising her head. I also noticed that she had increasing difficulty with breast feeding. Shortly afterwards, at 5 months of age, following a thorough investigation, she was diagnosed with spinal muscular atrophy (SMA1). How do parents feel when they are told that their beautiful, expressive, cheerful baby girl is suffering from a devastating disease for which there is no cure? That she will gradually yet swiftly lose her ability to move, babble and breathe? That she will lose her ability to eat without choking, and that she will probably die before reaching her second birthday? The earth slipped away from under my feet. I felt completely helpless. Suddenly, a dark cloud cast a shadow over our lives. My husband and I were facing the most horrible decision parents ever have to make: should we doom our daughter to a life without movement, a prisoner in her own body, not able to breathe or eat without machines and not use her voice to communicate with others, or should we let her go and not take any invasive measures to prolong her life. What guided us thorough this struggle was the decision that Daria had a right to live, to be happy and not suffer. We choose her happiness as our guidance.

Daria's rapid deterioration made us confront our new reality. It was chaotic. We decided that we had to be there for all our girls and tried to keep a sense of a normal routine. As the days went by, I felt as if I were riding an emotional roller coaster between two parallel universes. A bright light in this dark new reality was the warm embrace from the medical team that was caring for Daria. I felt that we were all partners in Daria's care, and that I was an integral part of the decision-making and management. I was not a passive observer but an active contributor. I felt that the doctors saw Daria for the sweet baby that she is and not just as an "SMA patient". They did not merely understand our struggle, they were a part of it, committed to making the journey together with our family. Our shared task was to take care of Daria, to make sure she did not suffer, and to help her keep smiling as much as she was able while being relentless in our search for a cure. And then, the impossible happened. We were presented with ground-breaking research about a possible life-saving drug for SMA called nusinersen.

We now had hope. Our doctors made tremendous efforts to work through the bureaucracy so that we could treat Daria with this drug, but time was not on our side. We knew that, with every day that passed, Daria was growing weaker and her condition more threatening. I was determined to keep our promise to her not to leave any stone unturned. With the encouragement and support of her doctors, and the help of many friends all over the world, we approached the manufacturers of the drug and their representatives in Israel. Endless calls, emails and even personally approaching the CEO of the company eventually bore fruit! The company decided to provide compassionate treatment to our little girl here in Israel. Our prayers had been answered and Daria was the first SMA patient in Israel to receive nusinersen.

The first summit of our journey has been conquered, but life with an SMA1 child brings new challenges for me and my family to face every day. The continuous support of Daria's medical team is crucial, and I feel that I have a strong and caring ally on my side. This partnership that I built with Dr. Lavie and the medical team is manifested by continuous medical consultations on one hand and happy updates on Daria's progress on the other.

Little Daria, our fighter, is now 3 years old. This month, she underwent her 11th treatment cycle. She is a beautiful, happy little girl with an infectious smile.

Despite treatment, Daria is dependent upon noninvasive ventilation and is fed through a gastrostomy tube, but she is able to move her extremities, to sit with support, and to babble, to the delight of each and every one of us.

Our partnership was, and still is, the driving force that made all the difference. 


\section{PHYSICIAN'S RESPONSE}

Hodaya's article is very illuminating, as it gives some very interesting and enriching insights into the challenges of care for children with SMA.

The principal pediatric pulmonologist in the team (M.L.) met Daria for the first time in December 2016, when she was 6 months of age. She arrived at the emergency department with an acute respiratory illness. She had recently been diagnosed with SMA1.

\section{What is SMA?}

Spinal muscular atrophy (SMA) is a rare neuromuscular disorder caused by an autosomal recessive mutation in the survival motor neuron 1 gene (SMN1). It is characterized by degeneration of the anterior horn cells in the spinal cord, resulting in progressive muscle weakness and atrophy [1]. SMA is the most common genetic cause of early infant death, with an incidence of approximately 1 in 11,000 live births [2]. SMA type 1 (SMA1), also known as Werdnig-Hoffmann disease, is the most severe form, with symptoms being observed before 6 months of age. There is no motor progress after the onset of symptoms, and the patients deteriorate progressively after diagnosis in nearly all cases $[1,3,4]$. The median age to ventilation is 10.5 months, and the median survival is from 8 to 13.5 months $[4,5]$. Historically, patients with SMA1 were treated palliatively or placed on chronic lifelong mechanical ventilation, thereby committing them to a life with no motor function. In December 2016, the United States Food and Drug Administration (FDA) approved nusinersen $\left(\right.$ Spinraza $\left.^{\circledR}\right)$, the first drug designated to treat SMA. Although not curative, the efficacy of nusinersen has been demonstrated in phase 3 studies with intrathecal injection and using a sham procedure as placebo in type I SMA infants younger than 6 months (ENDEAR, $n=121$ ), and late-onset non-ambulant SMA patients (between 2 and 12 years) (CHERISH, $n=126$ ). Clinical trials showed that type 1 patients live longer with motor milestones never previously observed in these patients. A more recent interim analysis in May 2019 in presymptomatic SMA infants treated with nusinersen (Narture, $n=25$ ) indicated that all children were alive at a median age of 35 month, without permanent ventilation, and had reached the sitting position [6]. The introduction of Spinraza was a breakthrough, representing a special and highly designated development that encouraged many patients and families worldwide.

Following nusinersen, a 2nd treatment for SMA was introduced. Zolgensma (formerly AVXS-101) is a gene replacement therapy comprising an adeno-associated viral vector containing the human SMN gene under control of the chicken beta-actin promoter. This therapy addresses the genetic root cause of the disease by increasing functional SMN protein in motor neurons and preventing neuronal cell death, resulting in improved neuronal and muscular function. Clinical trials of Zolgensma showed that the one-time gene replacement therapy was able to preserve respiratory function in a cohort of symptomatic SMA1 infants with two copies of the SMN2 gene; 70\% of patients who did not require assisted ventilation prior to treatment were able to continue without such support for $>2$ years following treatment $[7,8]$.

\section{Treating a Patient with SMA}

My (M.L.) first assessment of Daria revealed that she was in a very fragile condition. She was very hypotonic, with poor respiratory effort, and a weak cough. Her parents were very anxious, having only begun to understand and internalize her condition. I closed the door behind me and sat in front of them, with the bustle of the crowded emergency department behind us, and so began our first encounter that was the cornerstone of our relationship. I explained Daria's condition to them, the immediate threat to her life, and the options that were available to her. During the following weeks, in parallel with Daria's gradual deterioration, the medical team laid the foundation for a respectful, transparent partnership. My belief is that the parents' views and intuition regarding the best choices for their child are fundamental to 
optimal management and joint decision-making for a given patient. I had long conversations with Daria's parents about her prognosis and about the measures that can be taken to support her breathing. Both non-invasive aids and tracheostomy can prolong survival for SMA 1 patients, and it should be left up to the family to decide which, if either, they would like to use [9]. Our talks were profoundly emotional for me. That beautiful baby girl and her loving and caring parents gradually entered my heart. Unfortunately, when we first met, we were able to offer the family only supportive measures and no treatment, but shortly after the FDA approved nusinersen treatment for SMA.

The impossible indeed happened at that time. There was now a treatment for Daria's disease. I could not have been happier. Nusinersen is an antisense oligonucleotide designed to increase the expression of the SMA protein. It is given intrathecally at specific time intervals as a lifelong treatment. It was approved by the FDA in December 2016 and by the European Medicines Agency in June 2017 [10]. Patients with SMA1 who were treated with nusinersen have an improved event-free survival and have achieved motor milestones that sham-treated patients did not [11-13]. Our medical team and Daria's parents were determined to get access to this drug, but it had not yet been approved for use in Israel. We approached the pharmaceutical company that manufactures nusinersen and started negotiating the delivery of the drug to Daria in Israel. Bureaucracy, however, was challenging and time was pressing. Daria's parents, with our support, decided to take things into their own hands.

Daria's parents did not rest until the company approved the compassionate treatment with nusinersen. On January 2017, at the age of 8 months, Daria became the first SMA patient in Israel to receive nusinersen. After she received the first treatment, her father wrote on the precious drug ampoule the words "If you will it, it is no dream," words spoken by Theodore Herzl. Daria's father handed the ampoule to me and my eyes filled with tears. Following Daria, 11 more SMA1 babies in Israel have received urgent compassionate treatment. For Daria, the first step in her journey had been taken, with many more to come.

At the beginning of our joined journey (2017), Daria's parent's expectations were very optimistic. Our team on the other hand, was more cautious, mostly because respiratory trajectories data were lacking at that time. A recent study by Sansone et al. on the respiratory needs in patients with type 1 SMA treated with nusinersen in 118 patients may be in line with the parents' optimism. This study suggested that nusinersen may produce some improvement in the progression of respiratory impairment, both in terms of survival and the need for respiratory support, especially before the age of 2 years [14].

Daria is now 3 years old. With treatment and loving care of her parents, she has altered the natural history for SMA1 and gained some motor function. Parents report that she is a happy toddler who attends day care and communicates with her surroundings in an inspiring manner. This echoes Bach et al.'s work on SMA1 quality of life (QOL) which demonstrated a significantly more positive estimate of the QOL of SMA1 children by their care providers than by clinicians in general. Like Daria's parents, the care providers in that study also noted that the children were very happy and that their lives were very worthwhile [15]. For Daria and her family, our partnership in this journey was, and still is, the driving force that made all the difference.

\section{ACKNOWLEDGEMENTS}

We thank the participants of the study especially Daria and her family.

Funding. No funding or sponsorship was received for this study or publication of this article.

Authorship. All named authors meet the International Committee of Medical Journal Editors (ICMJE) criteria for authorship for this article, take responsibility for the integrity of 
the work as a whole, and have given their approval for this version to be published.

Disclosures. Dr. Lavie, Mrs. Nisnkorn, Dr. Sagi and Prof Amirav have nothing to disclose.

Compliance with Ethics Guidelines. This article is based on previously conducted studies and does not contain any studies with human participants or animals performed by any of the authors.

Data Availability. Data sharing is not applicable to this article as no datasets were generated or analyzed during the current study.

Open Access. This article is licensed under a Creative Commons Attribution-NonCommercial 4.0 International License, which permits any non-commercial use, sharing, adaptation, distribution and reproduction in any medium or format, as long as you give appropriate credit to the original author(s) and the source, provide a link to the Creative Commons licence, and indicate if changes were made. The images or other third party material in this article are included in the article's Creative Commons licence, unless indicated otherwise in a credit line to the material. If material is not included in the article's Creative Commons licence and your intended use is not permitted by statutory regulation or exceeds the permitted use, you will need to obtain permission directly from the copyright holder. To view a copy of this licence, visit http://creativecommons.org/licenses/by$\mathrm{nc} / 4.0 /$.

\section{REFERENCES}

1. Kolb SJ, Taylor JP. Spinal muscular atrophy. In Neurogenetics: scientific and clinical advances 2005.

2. Verhaart IEC, Robertson A, Wilson IJ, Aartsma-Rus A, Cameron S, Jones CC, et al. Prevalence, incidence and carrier frequency of 5q-linked spinal muscular atrophy-a literature review. Orphanet J Rare Dis. 2017;12:124. https://doi.org/10.1186/ s13023-017-0671-8.
3. De Sanctis R, Coratti G, Pasternak A, Montes J, Pane $\mathrm{M}$, Mazzone ES, et al. Developmental milestones in type I spinal muscular atrophy. Neuromuscul Disord. 2016;26(11):754-9. https://doi.org/10.1016/j. nmd.2016.10.002.

4. Kolb SJ, Coffey CS, Yankey JW, Krosschell K, Arnold WD, Rutkove SB, et al. Natural history of infantileonset spinal muscular atrophy. Ann Neurol. 2017; 82(6):883-91. https://doi.org/10.1002/ana.25101.

5. Finkel RS, McDermott MP, Kaufmann P, Darras BT, Chung WK, Sproule DM, et al. Observational study of spinal muscular atrophy type I and implications for clinical trials. Neurology. 2014;83(9):810-7.

6. De Vivo DC, Bertini E, Swoboda KJ, Hwu W-L, Crawford TO, Finkel RS, et al. Nusinersen initiated in infants during the presymptomatic stage of spinal muscular atrophy: Interim efficacy and safety results from the Phase 2 NURTURE study. Neuromuscul Disord. 2019;29(11):842-56. https://doi. org/10.1016/j.nmd.2019.09.007.

7. Mendell JR, Al-Zaidy S, Shell R, Arnold WD, RodinoKlapac LR, Prior TW, et al. Single-dose gene-replacement therapy for spinal muscular atrophy. N Engl J Med. 2017;377(18):1713-22.

8. Al-Zaidy S, Pickard AS, Kotha K, Alfano LN, Lowes L, Paul G, et al. Health outcomes in spinal muscular atrophy type 1 following AVXS-101 gene replacement therapy. Pediatr Pulmonol. 2019;54(2): 179-85.

9. Bach JR. The use of mechanical ventilation is appropriate in children with genetically proven spinal muscular atrophy type 1: the motion for. Paediatr Respir Rev. 2008;9(1):45-50.

10. Gidaro T, Servais L. Nusinersen treatment of spinal muscular atrophy: current knowledge and existing gaps. Dev Med Child Neurol. 2019;61(1):19-24.

11. Finkel RS, Mercuri E, Darras BT, Connolly AM, Kuntz NL, Kirschner J, et al. Nusinersen versus Sham Control in Infantile-Onset Spinal Muscular Atrophy. N Engl J Med. 2017;377(18):1723-32.

12. Finkel RS, Chiriboga CA, Vajsar J, Day JW, Montes J, De Vivo DC, et al. Treatment of infantile-onset spinal muscular atrophy with nusinersen: a phase 2 , open-label, dose-escalation study. Lancet. 2016;388:3017-26. https://doi.org/10.1016/S01406736(16)31408-8.

13. Aragon-Gawinska K, Seferian AM, Daron A, Gargaun E, Vuillerot C, Cances C, et al. Nusinersen in patients older than 7 months with spinal muscular atrophy type 1. Neurology. 2018;. https://doi.org/ 10.1212/WNL.0000000000006281. 
14. Sansone VA, Pirola A, Albamonte E, Pane M, Lizio A, D'Amico A, et al. Respiratory needs in patients with type 1 spinal muscular atrophy treated with nusinersen. J Pediatr. 2020. https://doi.org/10. 1016/j.jpeds.2019.12.047.
15. Bach JR, Vega J, Majors J, Friedman A. Spinal muscular atrophy type 1 quality of life. Am J Phys Med Rehabil. 2003;82(2):137-42. 